\title{
Development of IPS Learning Characterized by PAKEM in Primary School
}

\author{
Zuardi \\ Padang State University, Padang, Indonnesia \\ Corresponding e-mail: zuardi.msi@gmail.com
}

\begin{abstract}
The learning process in elementary school generally aims to develop all the potential that exist in the students themselves, both potential in the aspects of cognitive, affective aspects, as well as psychomotor aspects. One of them, learning IPS in elementary school needs to be arranged in a systematically, comprehensive, and integrated in the learning process towards maturity and success in community life. Jarolimek (1993: 8) expects that Social Knowledge Education should be able to develop aspects of knowledge and understanding (knowledge and understanding), attitude and value aspects as well as skill aspects of students. Student learning experience is not gotten just like that it needed teachers ability in developing basic knowledge that students have, because basically every student has knowledge as result of interaction with environment. Teachers need to develop learning strategy oriented on students (Student Centered) so that students are encouraged to participate Active, creative, effective and Fun (PAKEM). PAKEM is an approach to teaching that is used with certain methods and various teaching media insert with environmental arrangement in such a way that the learning process becomes active, innovative, creative, effective, and fun.
\end{abstract}

Keywords: PAKEM, cognitive, affective, psychomotor, systematic, comprehensive.

Topic Area: Collaborative and Problem-Based Learning

\section{INTRODUCTION}

Generally, the aim of learning process of various subjects in primary school is to develop students' potentials and capabilities. it is including the development of cognitive, affective and psychomotor of learning outcomes domains. Social Science s one of the subjects given to elementary school and junior high school students. The aim of this subjects is to provide students with comprehensive insight about events, facts, concepts, and generalizations social issues. Therefore, social science learning processes should be well prepared, systematically arranged, and comprehensive. More importantly, social science learning processes should be integrated with social life. it is aimed to prepare students towards maturity of thinking and success in community life. The purpose of teaching social science to young learners such as elementary school are to help students to develop the following capabilities:

a. Understanding the concepts related to people's life and the environment.

b. Obtaining basic skills for logical and critical thinking, curiosity, inquiry, problem solving, and skills in social life.

c. gaining commitment and awareness towards humanity's social values. d. being able to communicate, to work in group and to live a pluralistic society, local, national and global in tolerance.

Jarolimek (1993: 8) expects that students who learn social science should be able to develop knowledge in social lives and phenomena and understanding attitude and value as well as real life skills. Meanwhile, according to Schuncke (1988: 8-9) school is a place that hold a very important role in constructing students believe of values, norms and democratic behavior. It is teachers' responsibility to help student in understanding and implementing normative values, norms and democratic behavior.

Achieving the objectives of learning social science in elementary school, a proper learning strategy is needed to be developed. The learning processes should be active, creative, effective and enjoyable. Teachers require to develop studentoriented learning strategies or it is known as student centered learning. this learning orientation encourages students to actively participate actively in the learning process. 


\section{PROBLEMS}

Based on the explanation and the discussion about learning processes in social sciences subjects, the problems that are proposed in this study are:

a. what are the of learnings models that create an active, creative, effective and enjoyable social sciences learning processes?

b. what are the learning approaches that can improve the quality of social sciences learning processes?

c. what are the learning methods that can be used to create an active, creative, effective and enjoyable social sciences learning processes?

d. What is media that can improve the quality of social sciences learning processes?

\section{DISCUSSION}

Developing creative and innovative learning models for social sciences learning processes is needed to foster students' motivation and encourages students' active participation. There are several learning models that can be used. The learning models are discussed as follows:

A. Direct Instructional Model.

Direct instructional model is widely understood as learning through observation in social learning theory. John Dolard and Albert Bandura believe that most humans learn through selective observation and remember others' behavior. The basic ideal direct instructional model is that students learn by observing selectively and remembering teacher behavior. However, this model is not suitable to teach complex knowledges.

\section{B. Cooperative Learning Model.}

Jhon Dewey believes that class is small version of bigger society. it is the reflection real society. Therefore, learning activities in the classroom should provide students with real experiences working in group, learning to socialize and respect each other. Gordon Alport reminded that cooperation and working in groups will give better results. Class settings in cooperative learning need to meet three conditions, namely: (a) direct contact, (b) equally participate in group work, (c) an agreement among group members about the classroom setting.

\section{Problem Based Learning Model}

This model has some common traits of presenting students with authentic and meaningful issues that will make it easier for students to conduct inquiry. While the special features in this model is the presence of questions and problems, products and works, and the existence of cooperation.

\section{Model Learning Through Discovery} (Inquiry).

Discovery learning is a teaching model that emphasizes the importance of helping students understand the structure or key ideas of a discipline, students are actively involved in the learning process, and confident that learning will occur through personal discovery. Bruner, who pioneered the discovery learning model, believes that this model of discovery will stimulate students to investigate to find something. The learning model of this invention is more suitable for embedding concepts that can be found through experiments and investigations.

\section{Approach in Social Science Learning} processes

The learning approach is the basis of teachers' attitudes and perceptions of how learning activities will be carried out. It will be the basis for teacher action in conducting learning process activities. Social science learning approaches that can be used are as follows:
A. Environmental approach
B. Concept Approach
C. Inquiry Approach
D. A process skill approach
E. Problem-solving approach
F. The inductive-deductive approach
G. Value approach
H. Communicative approach
I. Historical approach
J. Thematic approach

These approaches can be chosen and applied to teachers to create an active, innovative, creative, effective, and enjoyable learning environment. UUPN. 20/2003 suggests that learning process should be interactive, inspiring, fun, challenging, motivating learners to participate actively, and providing sufficient space for initiative, creativity and independence, in accordance with the students' physical and psychological talents, interests and development.

Conventional learning paradigm needs to be changed with innovative learning model. there are several reasons for these conditions. The reasons are described as follows:

A. The immense flow of information grows continuously

B. Students needs to learn in various way to develop their potentials

C. Subjects mastery levels only aim for short period of time

D. The learning process should be integrated with real life problems. 


\section{IPS Learning Method}

Method is one component of learning that plays a role besides other components. Methods are ways or techniques that are considered efficient in delivering materials or learning materials to students. A teacher must be able to choose and determine the most effective learning methods in achieving learning goals.

Each method has its own advantages and disadvantages. Therefore, various learning methods are required to be implemented in social sciences learning processes. There are various kinds of learning methods that can be used in learning social sciences. Aziz Wahab (1997: 186) lists the learning method as follows:
A. Lecture method
B. Question and answer method
C. Discussion methods
D. Simulation method
E. Assignment method
F. Game method (game)
G. The story method
H. Methods of tourism work or field studies
I. Socio drama method
J. Role playing method
K. Method of exhibition (exposition)
L. Project method
Choosing and selecting an appropriate learning method to teach students one subject or material in social science studies requires to fulfill several criteria. The criteria that should be considered is described as follows:
A. Characteristics of subject matter that will be taught to students.
B. the facilities and and infrastructure that enable teachers to implement learning methods
C. students background and needs

\section{Media in Social Studies}

Media is one of the important aspect that can be used in supporting an active, creative, efektif and enjoyable learning processes. However, teachers should be wise in selecting a proper media to help students a specific knowledge. There are several aspects that can be considered by teachers in choosing a learning media. The aspects are

A. Objectivity

In choosing the media, it is necessary to ask for advice from peers, not on the personal pleasure of the teacher.

B. Learning program

The selected media should support the achievement of the learning objectives.

C. Target program
Students' background and needs are the priority in selecting learning media as well as the subject or material that will be delivered.

D. Situation and condition

Media must be adapted to the situation and conditions related to school facilities and infrastructure as well as the condition of the student's condition.

E. Quality of technique

The quality of this technique relates to image quality, audio recording or visual sound, or other tools.

F. Effectiveness and efficiency of use

Effectiveness concerns the optimal absorption of information by students, while efficiency is related to the expenditure of personnel, time and cost of how able to achieve optimal goals. Learning media has a variety and forms of various, but based on its development, the media can be classified into:

1) General and traditional Media

For example: blackboards, textbooks, magazines, reference books and more

2) Sophisticated media

For example: radio, TV, VCD, tape recorder,

3) Media that is innovative

For example: computers, internet, machinery that allows self-study.

(Suhanaji and Waspodo, 2003: 170)

While the types of media can be grouped as follows:

1) Teaching tools

For example: whiteboard, show boards, multipliers

2) Print media

For example: transparency, slide, film strip, charts, charts, models and realia,

3) Visual media

Examples: photos, maps, globe

4) Audio media

For example: the type of recorder, vocal cords, records and others

5) Audio-visual media

For example: television, VCD

6) Society as a learning resource

For example: resource persons, community leaders, life dynamics in society.

\section{CONCLUSIONS RECOMMENDATIONS}

AND

\section{Conclusion}

To improve the quality of social science study learning in elementary schools, teachers need to be active, creative and selective in applying learning models and approaches. In choosing and utilizing learning media needs to be adjusted to the 
characteristics of learning materials to be delivered. Submission of learning materials by applying varied learning methods will motivate student in following the learning process. Therefore, learning objectives can be achieved more effectively and efficiently. The use of instructional media needs to be considered objectively based on the facilities and infrastructures.

\section{Suggestions}

To improve the quality of teaching and learning process in social science studies, primary school teachers should apply effective, creative, innovative, effective and fun learning models. Different learning methods need to be implemented by teachers in Elementary Schools in varying and innovative ways to encourage student motivation and different abilities. social sciences teachers in Elementary School should be creative in using learning media capable of supporting the effectiveness of IPS learning activities in Elementary School.

\section{REFERENCES}

[1] Jarolimek, W., Demmelhuber, J., Bijak, M., \& Misgeld, U. (1993). CGP 55845A blocks baclofen, $\gamma$-aminobutyric acid and inhibitory postsynaptic potassium currents in guinea pig CA3 neurons. Neuroscience letters, 154(1), 31-34.

[2] Dewey, J. (1997). How we think. Courier Corporation.

[3] No, U. U. (2006). 20. 2003. Tentang sistem pendidikan nasional.

[4] Schuncke, G. M., \& Raffa, J. B. (1988). Elementary social studies: Knowing, doing, caring. MacMillan Publishing Company.

[5] Suhanadji, S., \& Waspodo, T. (2003). Pendidikan IPS 2.

[6] Wahab, A. A. (1997). Pendidikan kewarganegaraan. Jakarta: Depdikbud. 